\title{
Ground instability in the old town of Agrigento (Italy) depicted by on-site investigations and Persistent Scatterers data
}

\author{
F. Cigna ${ }^{1,}$, C. Del Ventisette ${ }^{1}$, G. Gigli ${ }^{1}$, F. Menna ${ }^{1}$, F. Agili $^{1}$, V. Liguori ${ }^{2}$, and N. Casagli ${ }^{1}$ \\ ${ }^{1}$ Department of Earth Sciences, University of Florence, Florence, Italy \\ ${ }^{2}$ Department of Civil, Environmental and Aerospace Engineering, University of Palermo, Palermo, Italy \\ *now at: British Geological Survey, Keyworth, UK
}

Correspondence to: F. Cigna (fcigna @bgs.ac.uk)

Received: 19 August 2012 - Accepted: 13 October 2012 - Published: 6 December 2012

\begin{abstract}
We combine on-site investigations with the interpretation of satellite Persistent Scatterers (PS) to analyse ground instability in the historic town of Agrigento, Italy. Geological and geomorphologic surveys, together with geostructural and kinematic analyses, depict the deformational patterns of the northwestern sector of the town, previously documented by extensive literature available for the neighbouring Valley of the Temples. The geological and geomorphologic maps are reconstructed by combining bibliographic studies, field surveys and aerial stereo-interpretation. ERS-1/2 PS data reveal deformation velocities up to 18$20 \mathrm{~mm} \mathrm{yr}^{-1}$ in 1992-2000 over the Addolorata landslide, and a sudden motion of $1.6 \mathrm{~cm}$ over the Bishop's Seminary in 1999. RADARSAT-1 PS data highlight velocities of $3.0 \mathrm{~mm} \mathrm{yr}^{-1}$ for St. Gerlando's Cathedral and reveals worsening of its structural instability since 2006. Ground instability of the town is controlled by low quality and high fracturing of the Agrigento formation rock masses, and the remarkable contrast between different mechanical behaviours of its calcarenite (brittle), silt and clay (plastic) facies. Slow landslides and widespread erosion are also recognised in the clays of the underlying Monte Narbone formation. Coexistence of these factors induces progressive retrogression of the edge of the Girgenti hill and damages the overlying historic buildings, whose stability and safe accessibility are nowadays almost compromised.
\end{abstract}

\section{Introduction}

Located in the central-southern coast of Sicily (Italy) and overlooking the Mediterranean Sea, the town of Agrigento formerly "Girgenti" - was founded by Gelon colonists in the 6th century BC as the ancient Akragas and then began one of the most important ancient Greek colonies. Today the city is generally known for its historic, archaeological and artistic value especially due to the extraordinary Valley of Temples, included in the World Heritage List of UNESCO in 1997.

Since ancient times, the expansion of the urban area was controlled by a particular geological setting, which caused widespread forms of ground instability threatening the historic old town, the Valley of the Temples, several buildings and the urban infrastructure. In the last century, landsliding processes affected the town and its surroundings, increased the geological risk for local population and damaged the cultural and environmental heritage belonging to the area (e.g., Cotecchia et al., 2005; and references therein).

On 28 February 1944, a landslide occurred along the northwestern sector of the town, involved the northern slope of the Girgenti hill and caused severe structural damages especially in the area of Bibbirrì Sq. and up to the railway at the bottom of the slope, i.e. the Lower Agrigento - Upper Agrigento railway, built in 1925 (Fig. 1; Commissione Ministeriale LL. PP., 1968). With less severe consequences it affected also the historic buildings along the edge of the slope, such as St. Gerlando's Cathedral (XI-XII century), the Bishop's Seminary (XVI-XVII century), St. Alphonsus Liguori's (XIX century) and Dell'Itria (XVI century) Churches. 


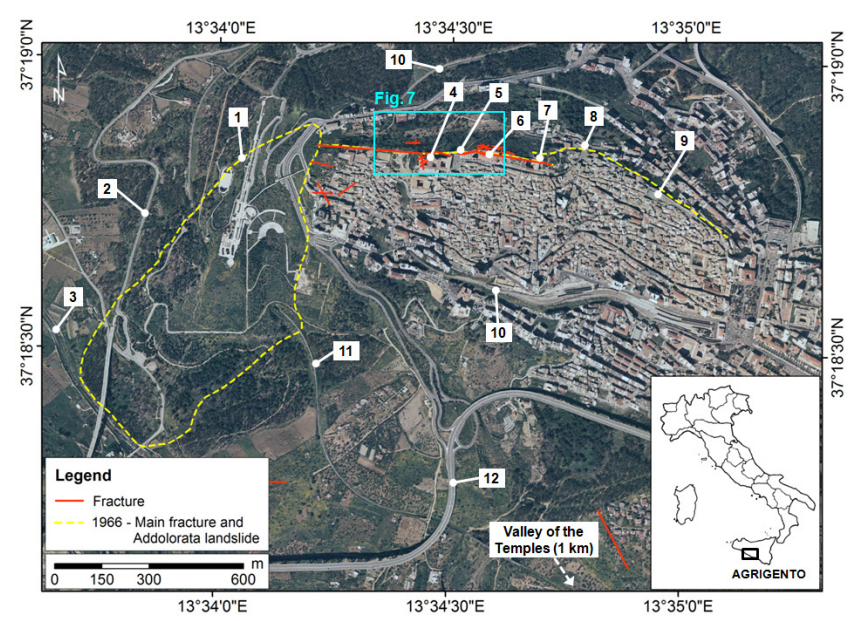

Fig. 1. Location map (inset, Google Earth 2010) and overview of the town of Agrigento (Italy). The most damaged sectors are located in the western and northwestern sectors of the Girgenti hill: (1) Addolorata landslide (19 July 1966); (2) SP1 secondary road; (3) Drago river; (4) Bishop's Seminary; (5) Diocesan Museum; (6) St. Gerlando's Cathedral; (7) St. Alfonso Liguori and Dell'Itria Churches; (8) Bibbirrìa Sq.; (9) Delle Mura St.; (10) Lower-Upper Agrigento railway; (11) Porto Empedocle railway line; (12) SS115 primary road. The Valley of the Temples is located $1 \mathrm{~km} \mathrm{SE}$ of the town.

Following this event, another large landslide affected the Arab quarter in the western sector of the town ("Addolorata landslide") on 19 July 1966. This landslide induced significant damages along the railway line to Porto Empedocle (SW of Agrigento) and the bridge over Drago river and forced the elements at risk to be relocated to Villaseta, $2 \mathrm{~km} \mathrm{SW}$ of Agrigento (Commissione Ministeriale LL. PP., 1968). Many fractures also developed in the northwestern sector of the hill and induced further damages on the overlying historic buildings such as the Cathedral, the Diocesan Museum (built in 1964) and the Seminary, as well as on many other private buildings located along Delle Mura St. and Plebs Rea St.

Furthermore, on 25 December 1976 another landslide ("Temple of Juno landslide") was reactivated by heavy rainfalls along the eastern slope of the town, in the area of the Valley of the Temples. This landslide blocked temporarily the access to the valley and damaged the Temple of Juno (e.g., Musso and Ercoli, 1988; Cotecchia et al., 2005).

As a response to the above-mentioned phenomena, many consolidation and reinforcement works and conservation and restoration actions were carried out in the last decades, especially in the NW sector of the historic old town. Among them, the consolidation of the foundations of St. Gerlando's Cathedral in 1981 and 1998, the reinforcement of the Bishop's Seminary in 1996 and the consolidation of the Diocesan Museum in 1996-1999. Nevertheless, field surveys and on-site investigations carried out by the local civil protection authorities confirmed an increase of hydrogeological hazard in
2005 (PCM, 2005), with major impacts and damages in the northwestern area of the old historic town (Fig. 1).

Following this recent worsening of local instability, we carried out an analysis of ground and structural instability based on the combination of bibliographic studies, conventional field investigations, photo-interpretation of aerial optical imagery and Persistent Scatterer Interferometry (PSI). This satellite remote-sensing technique is a widely accepted methodology for the precise estimation of ground displacements related to processes with slow kinematics (e.g., Colesanti et al., 2003; Hilley et al., 2004; Meisina et al., 2006; Herrera et al., 2009; Righini et al., 2012).

PSI can support conventional on-site data to get an improved overview and knowledge of the investigated phenomena, by: (i) allowing spatial and temporal characterisation of motion dynamics; (ii) overcoming issues related to installation of ground-based instrumentation and data acquisition in unstable areas; and (iii) providing retrospective estimates of ground motions (e.g., Bianchini et al., 2012; Hölbling et al., 2012; Cigna et al., 2012). These techniques have promising potential for long-term monitoring of geohazards, to understand both correlations with triggering factors (e.g., Farina et al., 2006; Cigna et al., 2011) and (in)direct impacts on the preservation of monuments exposed to geological and structural instability (e.g., Gigli et al., 2012; Tapete et al., 2012; Tapete and Cigna, 2012).

\section{Geological background and ground instability}

\subsection{Regional and local setting}

Agrigento is located at the edge of the Maghreb-Apennine thrust belt and its geological setting is connected with a geodynamic evolution dating back to the regressive phase of Caltanissetta basin, the central tectonostratigraphic domain of the orogenic front including the Gela Nappe. The MaghrebApennine thrust belt trends regionally E-W across Sicily, with the Gela Nappe forming a large arcuate salient along the thrust front. Structural trends in the nappe vary from a predominantly NE-SW orientation on the E, through E-W trending around Licata, to a NW-SE trend near Agrigento (Fig. 2). Deformation in the Caltanissetta basin is dominated by large open folds with amplitude of $1-3 \mathrm{~km}$ and half wavelength of $5-10 \mathrm{~km}$ across the general strike, characterising the surface geological and structural setting. Some of these folds may be cored by southward blind thrusts (e.g., Lickorish et al., 1999).

The geological setting of Agrigento municipality is characterised by the presence of a regressive Miocene and PlioPleistocene succession of the Gela Nappe, essentially consisting of clays, sand and calcarenite. Starting from the bottom of this geological succession, a basement from the Miocene and Pliocene can be distinguished (Tortonian terrigenous molasse deposits and Messinian rocks of the 

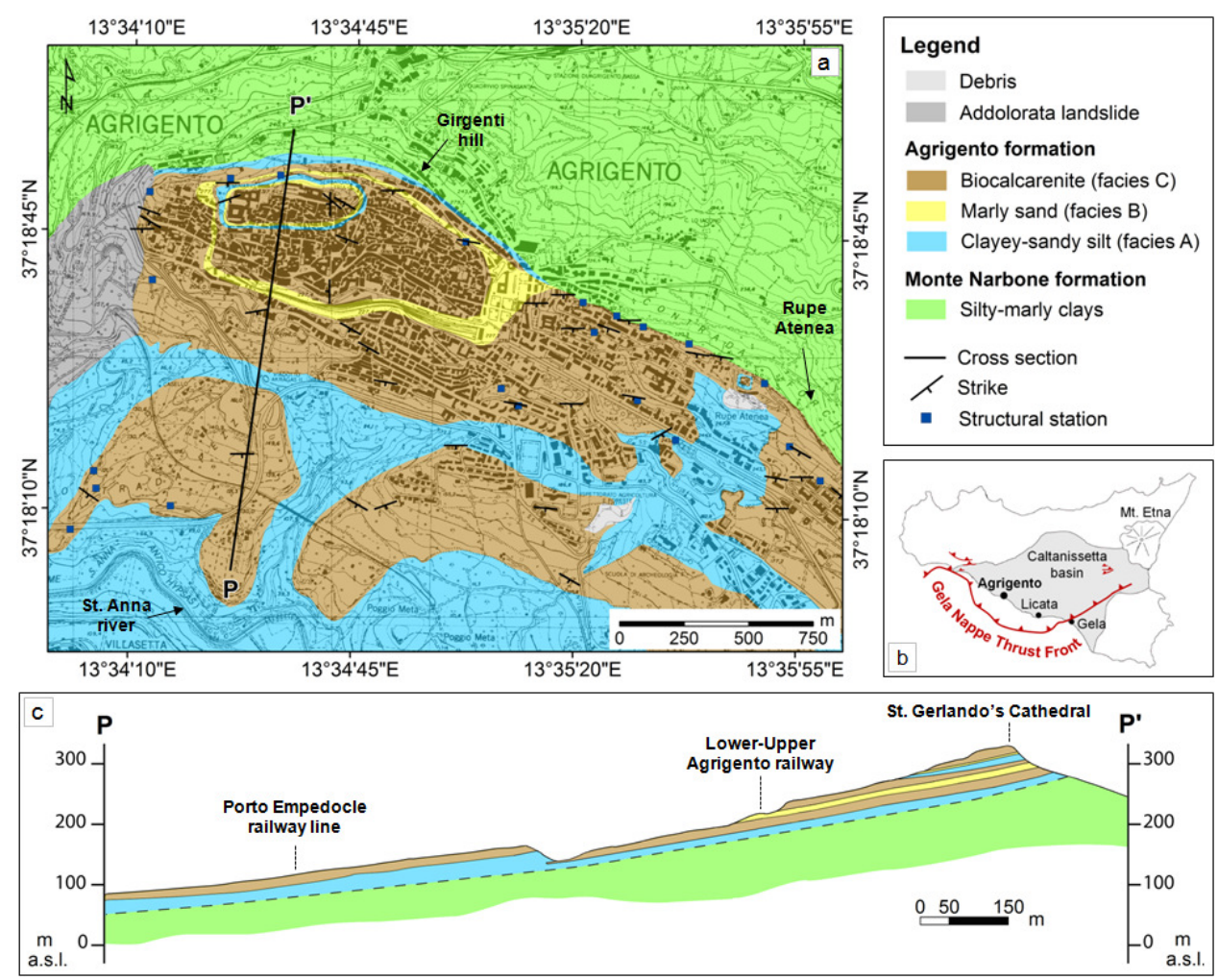

Fig. 2. (a) Geological map of Agrigento and its location (b) within the Caltanissetta basin (grey area) and the southern Gela Nappe (thrust front, red line). (c) Geological cross-section $P-P^{\prime}$.

Gessoso Solfifera series - evaporite limestone and gypsum). This is followed in transgression by the Trubi formation (Lower Pliocene) and, further up, by the Monte Narbone (Middle-Upper Pliocene) and the Agrigento (Lower Pleistocene) formations. Closing the stratigraphic succession, the terraced marine deposits of the Sicilian and Tyrrhenian ages (Pleistocene), and recent debris, alluvial and coastal deposits crop out (e.g., Servizio Geologico d'Italia, 1972; Grasso and Butler, 1991).

An asymmetrical syncline with $\mathrm{N}$-dipping and $\mathrm{E}-\mathrm{W}$ trending axis characterises the urban area of Agrigento and the Valley of Temples. The syncline was generated by tectonic stress during Lower Pleistocene, and its core consists of the pelitic Agrigento formation, discontinuously lying on the Monte Narbone clayey formation. The latter is made up by blue-grey silty marly clays (up to $200 \mathrm{~m}$ thick) with a fairly regular stratification highlighted by thin silty sand levels. It laid down in platform-lithofacies, with bathyal (300-400 m) depths. To the N, it crops out in the Rupe Atenea valley and the Girgenti hill, while to the $S$, it crops out along the coastline and in the deepest incisions (e.g., Cotecchia et al., 2005).

The Agrigento formation, overlapped upon the Monte Narbone one, consists of the alternation of three main facies (from the bottom to the top): clayey-sandy silt (facies A), marly sand (facies B) and biocalcarenite and biocalcirudite (facies C), often characterised by lateral transitions. Facies A has a thickness up to $15-20 \mathrm{~m}$ and is constituted by yellowgrey marly silt, including biocalcarenite levels of facies B and C. It lies on the biocalcarenite level (facies C, on-lap unconformity) and is covered by facies B on the top (erosion disconformity). Facies B is made up by marly sands with bioturbation and macrofossils, has generally a thickness up to $5 \mathrm{~m}$ and, at the top, gradually evolves to facies $\mathrm{C}$. This latter is constituted by calcareous sandstone, inside which bottomset, foreset and topset beds can be recognised. Its thickness varies from a few metres up to about $35-40 \mathrm{~m}$. Within the whole Agrigento formation, these cycles of facies A, B and $\mathrm{C}$, can be identified four times, corresponding to four eustatic changes recorded during Lower Pleistocene (e.g., Cotecchia et al., 2005; and references therein).

A 1:10000 geological map of the area (Fig. 2a) and a schematic cross-section (Fig. 2c) were reconstructed from geological and geostructural field surveys, integrated also with: (i) bibliographic studies (cf. above references); and (ii) past geological, geotechnical and geognostic campaigns and/or consolidation works carried out in the 1980s and 1990s, and in more recent years. Among them, the consolidation works of the Cathedral in 1981 and 1998, the Diocesan Museum in 1996-1999, the Seminary in 1994 and 1996, and St. Alphonsus Liguori's Church in 1999, as well as the recent 


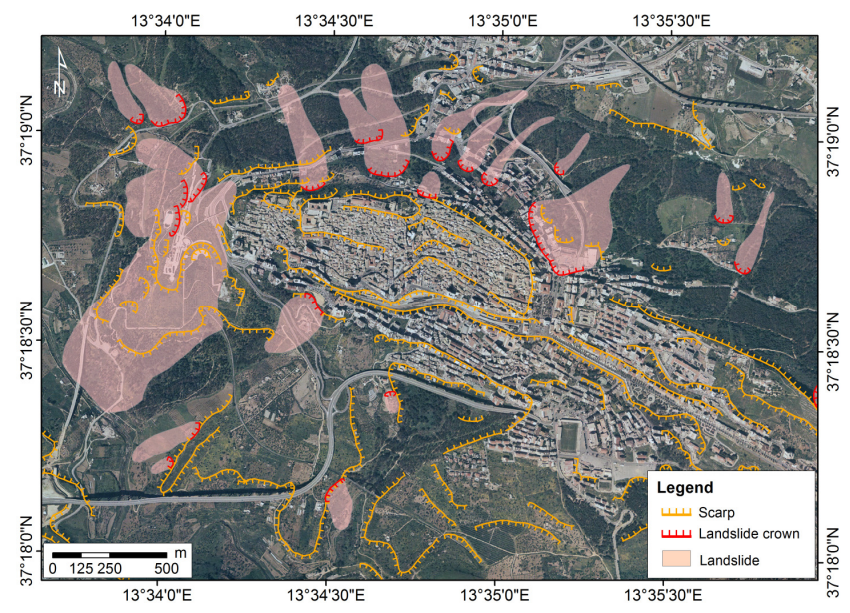

Fig. 3. Geomorphologic map of Agrigento obtained through geomorphologic field surveys and stereographic photo-interpretation of aerial photos, integrated with bibliographic studies.

geognostic campaigns carried out in the historic old town in 2005 and 2008.

Within the urban area only three cycles of facies A, B and $\mathrm{C}$ can be recognised. Most of the town lies over the lower biocalcarenite intercalation (facies C) of Agrigento formation, which extends from the Temple of Demetra on the E, and up to the Girgenti hill to the W. In the historic old area of the town this intercalation has a maximum thickness of $40 \mathrm{~m}$ decreasing toward SE, and an inclination of about 20 $22^{\circ}$ to the S. The underlying facies B and A of the same transgressive-regressive cycle have, respectively, a thickness of about $2-5 \mathrm{~m}$ and $10-15 \mathrm{~m}$. The second cycle of facies A, B and $\mathrm{C}$, overlaying the first one, has instead a total thickness lower than $30 \mathrm{~m}$. Its facies A (clayey-sandy silt) is not detectable, whereas facies B (marly sand) is very thick (about $20 \mathrm{~m}$ ) and biocalcarenite has a thickness of about $8 \mathrm{~m}$. The overlying third transgressive-regressive cycle, on which the historic area of the town is built, has a biocalcarenite facies with a thickness of about $20 \mathrm{~m}$, a very thin facies B, and a facies A up to 15-20 m thick (Fig. 2c). These three cycles constitute the northern flank of the large asymmetrical syncline that characterises the area of Agrigento.

\subsection{Geomorphology and ground instability}

The urban area develops over two hills with elevation of 200$350 \mathrm{~m}$ a.s.1.: the Girgenti hill on the W and the Rupe Atenea on the $\mathrm{E}$, which are divided from each other by a well-marked narrow valley (Figs. 3 and 4). The shape of these hills is elongated in the WNW-ESE direction, with a total longitudinal extent of about $3500 \mathrm{~m}$. These reliefs are characterised by monoclinal structure dipping about $20^{\circ}$ to the SSW, constituting the northern flank of the large asymmetrical syncline which characterises the whole area of Agrigento.

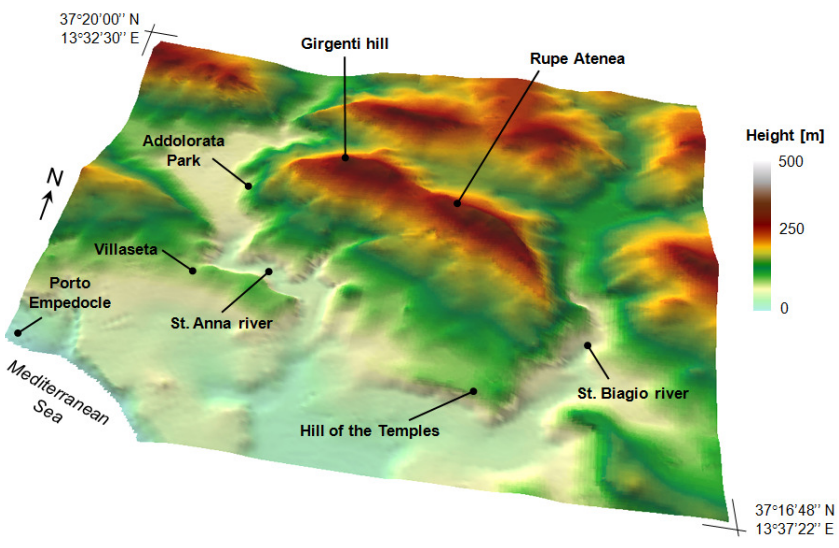

Fig. 4. 3-D view of the $20 \mathrm{~m}$ resolution Digital Terrain Model (DTM) of the area of Agrigento.

Along the N-S direction, the Girgenti hill and the Rupe Atenea have asymmetric morphologies characterised by highly steep northern slopes and southern slopes with less pronounced dip. This particular morphologic setting is controlled by the geological conditions of the area and the stratigraphic contact between the Monte Narbone and the Agrigento formations. To the $\mathrm{S}$, the city expands on a highland at a lower level (120-170 m a.s.1.), characterised by a steep hill (Hill of the Temples; to the SE) and a flat central valley (Valley of the Temples). The whole area - including the Girgenti hill and the Rupe Atenea to the $\mathrm{N}$ and the highland to the $\mathrm{S}-$ is surrounded and crossed by two rivers, St. Biagio on the $\mathrm{N}$ and the E, and St. Anna on the S and the W (Figs. 1 and 4). They flow together into the San Leone river to the $S$, in the area of the ancient harbour of the city, Porto Empedocle.

The different morphologies that characterise the area are consequences of a complex geological setting combined with widespread land processes, such as ground instability and erosion. These phenomena are influenced by the recent tectonic evolution of the area, past and current climatic conditions and also large extensive agricultural areas that expose plowed land to water flow and consequent soil loss. These processes, together with human activities, cause rapid evolution of the slopes and significant historical and recent landslide activity (Regione Siciliana, 2006).

In the past, the particular geological and geomorphologic setting of the area exposed the Agrigento and the Hill of the Temples to several ground instability (e.g., landslides occurred in 1944, 1966 and 1976), some of which are still active today. According to the landslide inventory produced in 2006 within the Hydrogeological Setting Plan of San Leone river basin (PAI, Piano di Assetto Idrogeologico; Regione Siciliana, 2006), more than $12 \mathrm{~km}^{2}$ of Agrigento municipality is affected by hydrogeological hazards. This area corresponds to $4.9 \%$ of the total extension of the municipality $\left(245 \mathrm{~km}^{2}\right)$. Extremely slow to rapid moving landslides, falls, topples, lateral spreads, creep, complex landslides, and 
erosion are observed. $68.5 \%$ and $18.5 \%$ of these phenomena are mapped in 2006 as active and dormant, respectively. Similarly to the landslide mapping of 2006, the Italian Landslide Inventory (IFFI, Inventario dei Fenomeni Franosi in Italia; ISPRA, 2007) identifies widespread landslide processes in the whole municipality.

The current overall instability conditions of the urban and suburban areas determine an alarming scenario, as summarised by the geomorphologic map of Agrigento urban area (Fig. 3; size reduced version of a 1:10000 map). This map was obtained through geomorphologic field surveys and stereographic photo-interpretation of 29 stereo aerial photographs at the $1: 8000$ scale, acquired in September 2003 with $\mathrm{E}-\mathrm{W}$ flight direction, height of $\sim 1200 \mathrm{~m}, 153 \mathrm{~m}$ focal length and longitudinal overlapping factor of $\sim 60 \%$ ("Volo Colore 2003 - lotto 2").

\subsubsection{Western slope}

The western sector of the Girgenti hill is affected by a series of landslides, whose last reactivation dates back to the Addolorata landslide (Figs. 2 and 3), occurred on 19 July 1966. This phenomenon affected an area of more than $0.5 \mathrm{~km}^{2}$ and was characterised by maximum ground displacements of about $0.8 \mathrm{~m}$ (Commissione Ministeriale LL. PP., 1968).

Recent morphological and structural observations highlighted that this landslide was a reactivation of an old phenomenon, which was caused by a combination of terrain layout and local morphology (Cotecchia et al., 2005). This particular setting made kinematically possible the translational sliding of the main body along a shear surface located within the clay terrains underneath the calcarenite bed.

Today, the area covered by the Addolorata landslide is still affected by ground instability, which is likely accelerated by human activities. The Hydrogeological Setting Plan classifies the instability as a dormant complex landslide (according to WP/WLI, 1993), but most of its area is affected by creep. Evidences of damages to the urban infrastructure, especially in the areas of the secondary road SP1 and the Addolorata Park, can be observed (Fig. 5).

\subsubsection{North-western slope}

Although most of the city is developed on a stable area, many predisposing factors (i.e., stratigraphy, tectonics, morphology, exogenous agents) led to the development of localised falls and topples, as well as slides involving the entire northwestern slope of the Girgenti hill, at the edge of the Agrigento formation (i.e., landslides occurred in 1944 and 1966). These phenomena determined serious damages to various historic and monumental buildings of Agrigento Diocese (e.g., St. Gerlando's Cathedral, Diocesan Museum, Bishop's Seminary; Fig. 6) and also private buildings, some of which were evacuated in the past.
Although some of these phenomena are now naturally stabilised, some evidences of active instability are still observable. For instance, a large sector spreading from the top to the bottom of the northwestern slope of the Girgenti hill, is affected by active complex landslides involving the terrains of the Agrigento and the Monte Narbone formations. The main scarps of these phenomena can be easily recognised on the slope, between the Diocesan Museum and the Bishop's Palace.

In this area, ground instability is generally induced by the geostructural setting which shows the overlaying of terrains with a brittle behaviour (calcarenite) on plastic behaviour lithotypes (clayey sandy silts and marly sands). The instability is accelerated by the layout of the Agrigento formation and the local syncline structure, which cause the different lithologies to be overlapped along tilted surfaces, as already observed by Cotecchia et al. (2005) for the Valley of the Temples.

Slow downstream movements and erosion of clayey deposits cause minor damages to the infrastructure located at the toe of the northern slope of the Girgenti hill. Instability of the clayey deposits induces the overlying jointed calcarenite to suddenly and rapidly slide, topple or fall, producing many damages in the buildings located at the edge of the slope. Several man-induced factors also influence and control the instability of the area. Building construction, calcarenite quarrying inside the built-up areas, groundwater overexploitation and, frequently, uncontrolled or unauthorised building works, likely act as local triggers for ground instability.

St. Gerlando's Cathedral and the Bishop's Seminary, already subject to many repairing and reinforcing interventions in the past (e.g., in 1981, 1996 and 1998), are now affected by widespread damages and cracks (Fig. 6). Ceiling, floor and columns of the Cathedral are highly fractured, especially in the northern aisle, facing the unstable slope. These cracks compromise the structural stability of the building and many temporary interventions have been already activated to reduce the risk of collapses. Two different sub-vertical fracture planes can be visually distinguished inside the Cathedral. They are characterised by dip direction of $\sim 185^{\circ}$ (almost parallel to the edge of the slope) and $\sim 315^{\circ}$.

The discontinuities that characterise the interior of the Cathedral and its façade also continue along the entire length of the outside staircase. The latter is affected by an evident fracture line which extends to the W up to the Seminary and, to the E, continues up to St. Alphonsus Liguori's Church. Inside the Seminary, the cracks are concentrated on the ground floor of its northwestern side, close to the edge of the calcarenite layer. Fractures are located mainly on ceiling and walls, and two main discontinuity planes can be identified, both dipping at an angle of $\sim 80-85^{\circ}$ and with a dip direction of $120^{\circ}$ and $190^{\circ}$. 

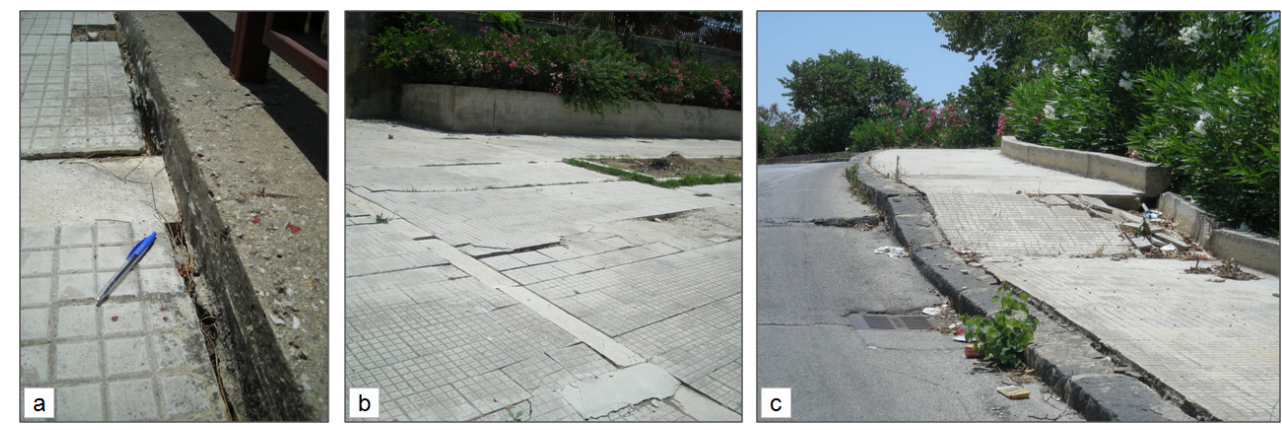

Fig. 5. Example of damages observed in the Addolorata Park and its road infrastructure.
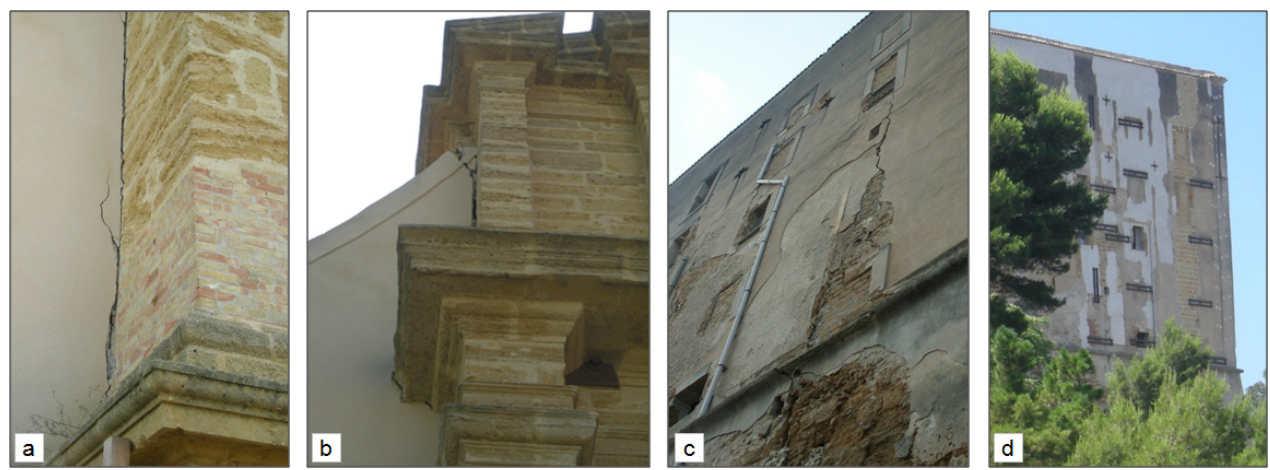

Fig. 6. Example of damages and cracks on the façade of St. Gerlando's Cathedral (a-b) and the Bishop's Seminary (c-d).

\subsection{Geostructural and geomechanical analysis}

We analysed the main joint distribution and characteristics for the most damaged sectors of the northwestern urban area. Along the edge of the Girgenti hill, calcarenite and marly sand deposits are affected by severe fracturing. Erosion and dissolution processes also contribute to general structural weakening.

Along the northwestern sector of the hill, near the Cathedral and the Seminary, we performed a detailed geomechanical survey to identify the main discontinuity planes and their mechanical properties (Tables 1 and 2). Together with the properties of the intact rock (e.g., compressive strength, modulus of elasticity), and the boundary conditions (e.g., on-site stress, groundwater pressure and flow), these parameters allowed us to determine the geomechanical properties of the rock mass of the Agrigento formation.

Point Load tests were carried out by following the guidelines of the International Society for Rock Mechanics (ISRM, 1985). Their results revealed that in this area the calcarenite and marly sands of the Agrigento formation are characterised by Uniaxial Compressive Strength (UCS) of $\sim 8 \mathrm{MPa}$ and tensile strength of $\sim 0.5 \mathrm{MPa}$ (Table 2).

The rock mass characterisation and the quantitative description of discontinuities were made according to the recommendations of the ISRM (1978) by using the scanline survey approach. Although the geostructural data of all the detected and measured fractures showed a significant dispersion, three main discontinuity modal planes were identified, as shown in Fig. 7 and Table 1.

These planes were detected through the statistical analysis of poles by using the probabilistic distribution of Fisher (1953) and consisted of: (i) one bedding plane dipping $15^{\circ}$ with dip direction of $184^{\circ}$ (i.e., BP1); and (ii) two joint sets dipping sub-vertically in the direction $270^{\circ}$ (i.e., JP1) and $31^{\circ}$ (i.e., JP2), which are perpendicular and oblique to the main slope, respectively (Fig. 7b and Table 1). Their joint spacing ranges from few decimetres up to metres, and, thus, isolates rock wedges of different sizes.

The degree of fracturing of the rock mass was then evaluated through the RQD (Rock Quality Designation; Deere, 1964) index, calculated for each scanline survey by applying the following equation proposed by Hudson and Priest (1983):

$\mathrm{RQD}=100 \times(0.1 \times \lambda+1) \times e^{-0.1 \times \lambda}$

where $\lambda$ is the apparent frequency of discontinuities along the scanline.

The resulting values of RQD ranged between $98 \%$ and $100 \%$, so the rock mass quality was classified as excellent. However, the RQD only represents the degree of fracturing of the rock mass and does not take into account the strength 
Table 1. Major characteristics of three main discontinuity planes (one bedding and two joint planes), measured in the northwestern sector of the Girgenti hill. $\alpha$, dip direction; $\beta$, dip; $T_{x}, T_{d}$ and $T_{r}$, percentage of joint termination, respectively, continuing beyond the outcrop, ending at intersection with other joint, ending against intact rock; $L$, joint length; $e$, aperture; JRC, Joint Roughness Coefficient; JCS, Joint Compressive Strength; $\tau$, shear strength.

\begin{tabular}{|c|c|c|c|c|c|c|c|c|c|c|c|c|}
\hline \multirow{2}{*}{ Typology } & \multicolumn{2}{|c|}{ orientation } & \multirow{2}{*}{$\begin{array}{r}\text { spacing } \\
X(\mathrm{~m}) \\
\end{array}$} & \multicolumn{4}{|c|}{ persistence } & \multirow{2}{*}{$\begin{array}{l}\text { aperture } \\
e(\mathrm{~mm}) \\
\end{array}$} & \multirow{2}{*}{$\begin{array}{r}\text { roughness } \\
\text { JRC }\end{array}$} & \multirow{2}{*}{$\begin{array}{l}\text { strength } \\
\text { JCS (MPa) }\end{array}$} & \multicolumn{2}{|c|}{ infill material } \\
\hline & $\alpha\left({ }^{\circ}\right)$ & $\beta\left({ }^{\circ}\right)$ & & $T_{x}(\%)$ & $T_{d}(\%)$ & $T_{r}(\%)$ & $L(\mathrm{~m})$ & & & & type & $\tau(\mathrm{kPa})$ \\
\hline Bedding Plane (BP1) & 184 & 15 & - & - & - & - & - & - & 12 & 3 & - & - \\
\hline Joint Plane (JP1) & 270 & 88 & 3.1 & 75.0 & 13.3 & 11.7 & 3.3 & 48 & 13 & 3 & loose, altered & $25-50$ \\
\hline Joint Plane (JP2) & 31 & 88 & 2.4 & 70.8 & 29.2 & 0.0 & 2.5 & 212 & 14 & 3 & loose, altered & $25-50$ \\
\hline
\end{tabular}
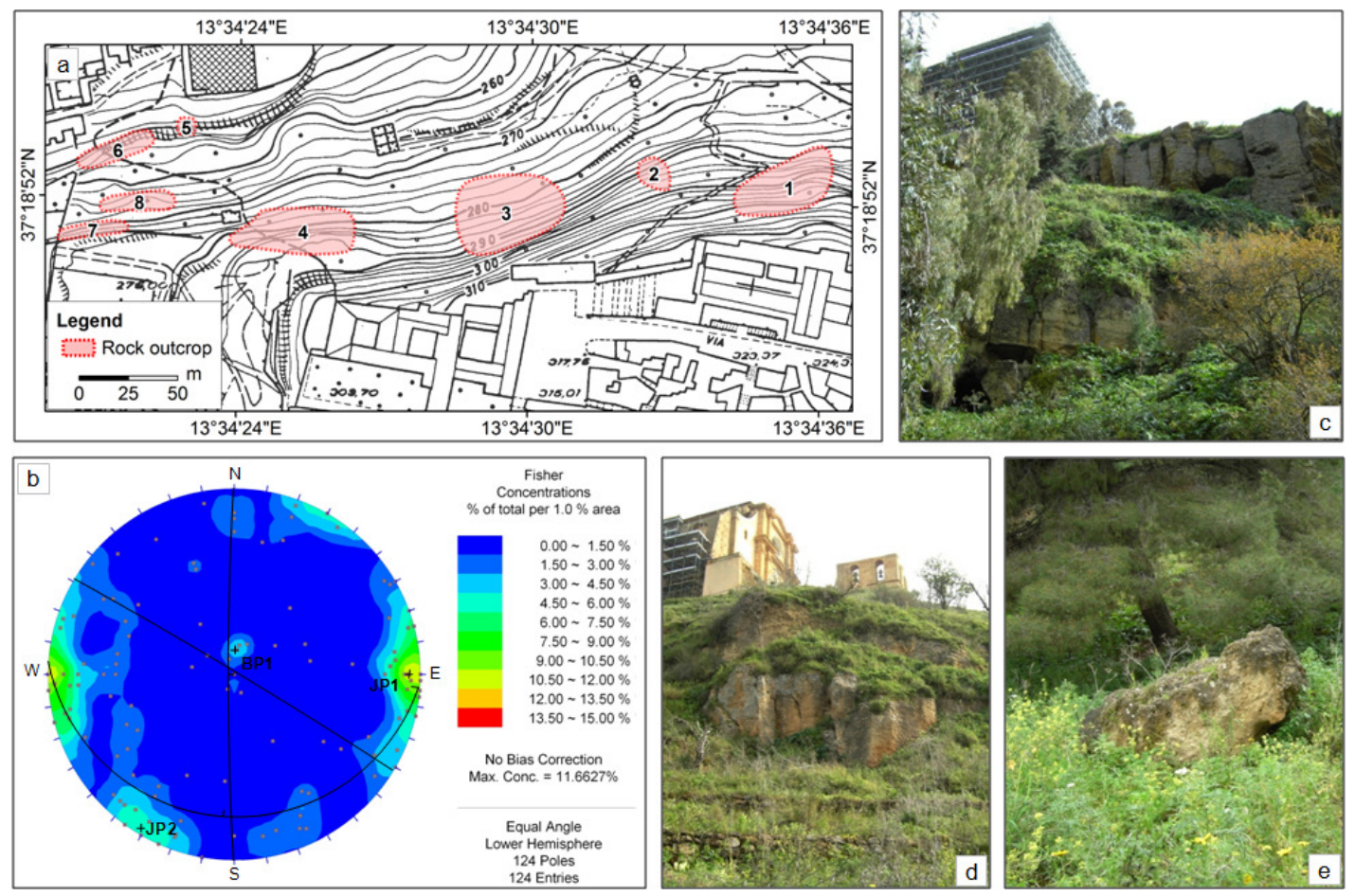

Fig. 7. (a) Distribution of analysed rock outcrops in the northwestern slope of the Girgenti hill. (b) Equal-angle stereographic projection (lower hemisphere) of discontinuity poles, contour plots and modal planes of structural data (plotted with Dips software, Rocscience Inc.). Characteristics of the three main discontinuity modal planes are summarised in Table 1. Photos of outcrops n. 4 (c) and n. 2 (d), and a detached block (e) taken in 2007.

Table 2. Main characteristics of the rock mass in the northwestern sector of the Girgenti hill.

\begin{tabular}{ll}
\hline Parameter & Value \\
\hline Uniaxial Compressive Strength, UCS (MPa) & 8.27 \\
Tensile strength (MPa) & 0.49 \\
Alteration & Fairly altered \\
Structure & Irregularly jointed \\
Block dimensions (m) & $0.6-2.0$ \\
Volumetric joint count, $J_{\mathrm{V}}\left(1 \mathrm{~m}^{-1}\right)$ & 0.74 \\
Rock Quality Designation, RQD $(\%)$ & $98-100$ \\
\hline
\end{tabular}

of the rock or mechanical and other geometrical properties of the joints such as persistence and aperture. Thus, it only reflects partially the rock mass quality.

\subsection{Kinematic analysis}

By accounting for the geometry of the northwestern slope of the Girgenti hill and the characteristics of its discontinuities, we carried out a kinematic analysis to assess the likelihood for certain instability mechanisms to occur. This analysis refers to the study of movements without reference to the forces that produce them, and in the case of Agrigento aims to evaluate whether the observed building damages 


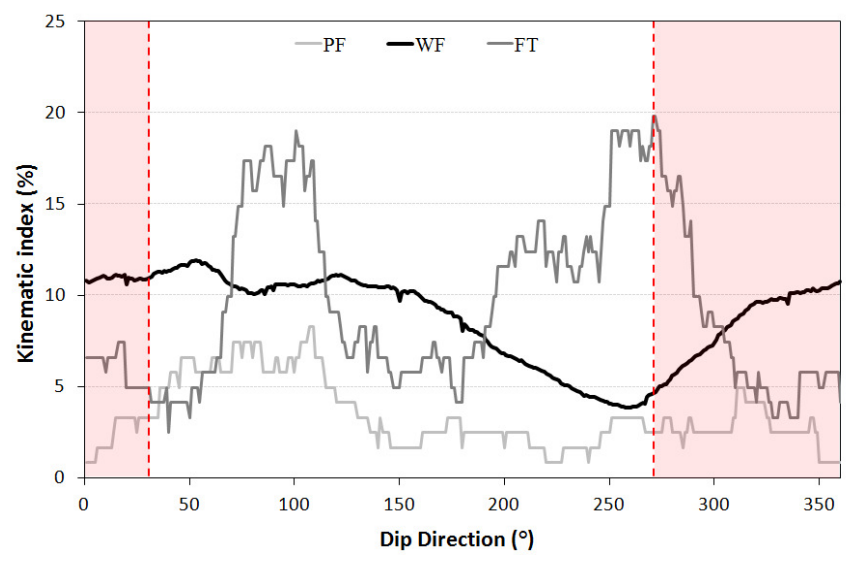

Fig. 8. Constant dip quantitative kinematic analysis for Plane Failure (PF), Wedge Failure (WF) and Flexural Toppling (FT). Values of the kinematic index for PF, WF and FT indicate the likelihood for the respective instability mechanisms to occur. Red areas show the range of the dip direction for the slope in the northwestern sector of the Girgenti hill.

and ground motions are amplified by the presence of unfavourably oriented discontinuities.

The instability mechanisms that we investigated by using this approach are: (i) Plane Failure, PF; (ii) Wedge Failure, WF; and (iii) Flexural Toppling, FT (Goodman and Bray, 1976; Hoek and Bray, 1981; Hudson and Harrison, 1997).

Casagli and Pini (1993) introduced the "kinematic hazard indexes" associable to each instability mechanism. These indexes can be calculated by counting those poles and discontinuities which fall within critical areas of the stereographic projection that satisfy PF, WF and FT conditions. These areas are defined by geometrical considerations on the planes along which the movement of the different blocks may occur and are referred to a certain friction angle.

The mechanical properties of discontinuities that we employed for the kinematic analysis were calculated by applying the empirical Barton criterion (Barton and Choubey, 1977). The latter uses an empirical relationship between the shear strength of the rock joints and the normal stress, which is based on the values of the Joint Roughness Coefficient (JRC), the Joint Compressive Strength (JCS) and the residual friction angle. Values of JCS and JRC were evaluated during the field surveys, the latter by using the JRC profiles of Barton and Choubey (1977). A basic friction angle $\phi_{\mathrm{b}}$ of $34^{\circ}$ was selected based on the lithologic characteristics of the outcropping materials (Table 2). The equivalent Mohr-Coulomb parameters at low normal stress were calculated and resulted in a friction angle $\phi$ of $38^{\circ}$.

The employed quantitative approach for the kinematic analysis considered a fixed slope dip of $70^{\circ}$. The index for each instability mechanism was then calculated by varying the slope dip direction from $0^{\circ}$ to $360^{\circ}$, in order to consider all the possible orientations of a slope.
In Fig. 8, the kinematic indexes of PF, WF and FT are plotted for each slope dip direction, and reveal the most unfavourable slope orientations for the main instability mechanisms. As observable from the plot, the highest kinematic indexes are associated to flexural toppling and wedge failure, with FT index up to $18-20 \%$ for dip directions of $80-110^{\circ}$ and $250-280^{\circ}$, and $\mathrm{WF}$ index up to $10-12^{\circ}$ for dip directions of $0-150^{\circ}$ and $310-360^{\circ}$.

On the other hand, the kinematic index of plane failure does not exceed 5-7\% for any values of the dip direction. Most probable mechanisms associated to the ranges of dip directions observed for the northwestern sector of the Girgenti hill (i.e., $270-360^{\circ}$ and $0-30^{\circ}$ ), are the flexural toppling (with FT index up to $20 \%$ ) and the wedge failure (with WF index up to $11 \%$ ).

\section{Satellite monitoring in 1992-2007}

We complemented the on-site investigations with a satellite study based on Persistent Scatterer Interferometry (PSI) data, which allowed the retrospective study of past ground motions occurred over the area of Agrigento in 1992-2007.

\subsection{Input PSI data}

Two stacks of satellite SAR data acquired by ERS-1/2 and RADARSAT-1 satellites were processed by TeleRilevamento Europa (TRE) using the PSInSAR ${ }^{\mathrm{TM}}$ (Permanent Scatterers InSAR; Ferretti et al., 2001) technique, developed by Politecnico di Milano (POLIMI) in 1999 and belonging to the PSI approaches.

The analysis was carried out by using: (i) 66 ERS-1/2 images acquired along descending orbits in 11 November 1992-23 December 2000 and with nominal temporal resolution of 35 days; and (ii) 54 RADARSAT-1 S3 (Standard Beam Mode 3) images acquired along ascending orbits in 21 March 2003-11 May 2007 and with revisiting time of 24 days.

Both the SAR sensors onboard ERS-1/2 and RADARSAT1 employ C-band radar signals, with wavelength $\lambda$ of $5.66 \mathrm{~cm}$ and frequency $f$ of $5.3 \mathrm{GHz}$. The Line of Sight (LOS) of ERS-1/2 in descending mode employs look angle $\theta$ of $23.1^{\circ}$ (measured between LOS and vertical direction), and is tilted of $12.8^{\circ}$ to the $\mathrm{N}$ with respect to the $\mathrm{W}$ direction. The RADARSAT-1 S3 LOS in ascending mode is characterised by $\theta$ of $32.3^{\circ}$, and its tilt with respect to the E direction is $10.3^{\circ}$ to the $\mathrm{N}$ (Table 3 ).

With regard to ERS-1/2 data, the descending stack was chosen to exploit its better temporal coverage in the Italian territory, considering also the very low frequency of ERS$1 / 2$ ascending acquisitions. Whereas, to study more recent ground motions the RADARSAT- 1 ascending data was selected to exploit a shorter revisiting time (24 days) and to get 
Table 3. Characteristics of ERS-1/2 and RSAT-S3 (RADARSAT-1 in Standard Beam Mode 3) PSI analyses in Agrigento. Average PS density is calculated for whole analysed area $\left(\sim 2 \mathrm{~km}^{2}\right)$, while maximum density is referred to the inner urban area. $\theta$, look angle, measured between LOS and vertical direction; desc, descending; asc, ascending.

\begin{tabular}{|c|c|c|c|c|c|c|c|c|}
\hline $\begin{array}{l}\text { Data } \\
\text { stack }\end{array}$ & $\begin{array}{l}\text { Repeat cycle } \\
\text { (days) }\end{array}$ & $\begin{array}{l}\text { Directional } \\
\text { cosines }\end{array}$ & $\begin{array}{l}\theta \\
\left({ }^{\circ}\right)\end{array}$ & $\begin{array}{c}\text { Temporal } \\
\text { coverage }\end{array}$ & $\begin{array}{l}\mathrm{N} . \\
\text { scenes }\end{array}$ & $\begin{array}{l}\text { N. } \\
\text { PS }\end{array}$ & $\begin{array}{l}\text { Average density } \\
\left(\mathrm{PS} \mathrm{km}^{-2}\right)\end{array}$ & $\begin{array}{l}\text { Maximum density } \\
\left(\mathrm{PS} \mathrm{km}^{-2}\right)\end{array}$ \\
\hline ERS-1/2 desc & 35 & $\begin{array}{l}+0.38307(\mathrm{E}) \\
-0.08700(\mathrm{~N}) \\
+0.91961(\mathrm{Z})\end{array}$ & $23.1^{\circ}$ & 11 Nov 1992-23 Dec 2000 & 66 & 1155 & 577 & 926 \\
\hline RSAT-S3 asc & 24 & $\begin{array}{l}-0.52571(\mathrm{E}) \\
-0.09530(\mathrm{~N}) \\
+0.84531(\mathrm{Z})\end{array}$ & $32.3^{\circ}$ & 21 Mar 2003-11 May 2007 & 54 & 1824 & 912 & 1437 \\
\hline
\end{tabular}

higher precision and better spatial density of measures (i.e., PS km${ }^{-2}$ ).

Despite the better suitability of descending data to analyse the western sector of the town (predominantly oriented in the SW, W and NW directions), only the ascending geometry was used for the RADARSAT- 1 analysis due to the availability of a more consistent data stack of ascending scenes with respect to the descending ones. Nevertheless, the ascending acquisition mode was still well suitable to capture the structural deformation affecting the old historic area (subvertically oriented) and also the ground instability affecting the SE-facing portions of the Addolorata landslide, as described in detail in the following section.

The Shuttle Radar Topography Mission (SRTM) Digital Elevation Model (DEM) with a 3 arcsec resolution $(\sim 90 \mathrm{~m})$ was used during the PSInSAR ${ }^{\mathrm{TM}}$ processing for the initial subtraction of the topographic phase components. The precision of the topographic information was then improved during the processing to get height values as precise as $1-1.5 \mathrm{~m}$.

The processing was focused on the urban and suburban area of Agrigento, for a total extension of $\sim 2 \mathrm{~km}^{2}$. During the processing of the ERS-1/2 1992-2000 stack, the image acquired on 1 August 1998 was selected by TRE as the master (temporal reference for the creation of all the interferograms), while for the 2003-2007 RADARSAT-1 stack, the 23 September 2004 image was used.

By following the standard processing approach of the PSInSAR $^{\mathrm{TM}}$ technique (Ferretti et al., 2001), a simple linear model of phase variation through time was employed by TRE for the extraction of the phase components related to ground deformation.

The reference point locations for the ERS-1/2 and RADARSAT- 1 analyses were identified over two areas assumed to be devoid of ground motions, by taking into account not only their geological and geomorphologic properties, but also the phase coherence distribution of the two SAR stacks. Geographic coordinates of ERS-1/2 reference point are $13^{\circ} 39^{\prime} 55^{\prime \prime} \mathrm{E}, 37^{\circ} 19^{\prime} 25^{\prime \prime} \mathrm{N}$ (outside Fig. 9a), whereas for RADARSAT-1 reference point they are $13^{\circ} 34^{\prime} 52^{\prime \prime} \mathrm{E}$, $37^{\circ} 18^{\prime} 60^{\prime \prime} \mathrm{N}$ (Fig. 9b).

\subsection{Analysis and interpretation}

The PSInSAR ${ }^{\mathrm{TM}}$ processing allowed the identification of more than 1100 Permanent Scatterers (PS) in the time interval 1992-2000 (ERS-1/2 data) and more than 1800 PS in 2003-2007 (RADARSAT-1 data), with an average PS density relative to the whole analysed area higher than $550 \mathrm{PS} \mathrm{km}^{-2}$ and $900 \mathrm{PS} \mathrm{km}^{-2}$, respectively (Table 3). A remarkable concentration of radar targets was detected in the areas with high density of man-made structures returning stable radar signals to the satellite, such as buildings, bridges, metallic devices along the main roads, antennas and rock outcrops.

PS motion velocities reveal a general stability of the whole urban area in both 1992-2000 and 2003-2007 (Fig. 9), with very few PS characterised by rates higher than $\pm 1.5 \mathrm{~mm} \mathrm{yr}^{-1}$ estimated along the LOS of ERS-1/2 and RADARSAT-1 satellites. Positive and negative PS deformation values indicate, respectively, movements toward and away from the satellite.

Velocity standard deviations range between 0.41 and $0.55 \mathrm{~mm} \mathrm{yr}^{-1}$ for the ERS-1/2 dataset, while for the RADARSAT-1 velocities they are between 0.11 and $0.61 \mathrm{~mm} \mathrm{yr}^{-1}$. For both the datasets modal values of the standard deviations are $0.50 \mathrm{~mm} \mathrm{yr}^{-1}$, hence PS velocities can be averagely considered as precise as $0.50 \mathrm{~mm} \mathrm{yr}^{-1}$.

Taking into account the orientation of the satellite ERS-1/2 and RADARSAT-1 LOS, the sensitivity to vertical motions of the available PS data is $\sim 85 \%$ for RADARSAT- 1 and $\sim$ $92 \%$ for ERS- $1 / 2$, while to E-W motions this is $\sim 53 \%$ for RADARSAT- 1 and $\sim 38 \%$ for ERS-1/2. On the other hand, pure N-S motions are sensed by both acquisition geometries as only $\sim 9 \%$, hence actual motions along the $\mathrm{N}-\mathrm{S}$ direction might be up to an order of magnitude higher than those seen by the PS dataset.

To ease the readability of the PS time series, we applied a rescaling in time and translated the displacements records of each series to the first acquisition of each dataset, i.e., 11 November 1992 for the ERS-1/2 dataset and 21 March 2003 for the RADARSAT- 1 one. The objective of this post-processing step was to set a new temporal reference 


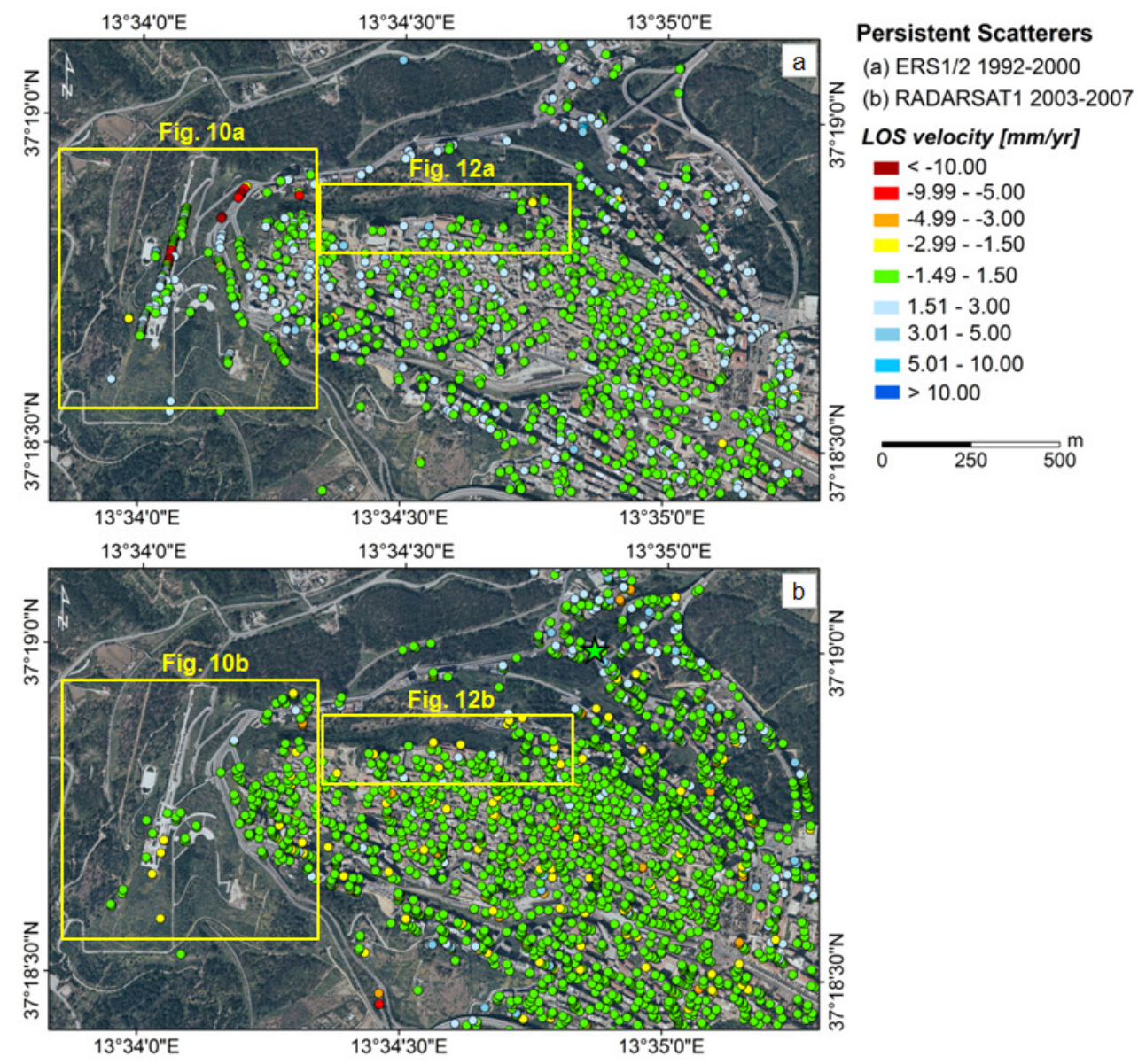

Fig. 9. 1992-2007 PS motion velocities in Agrigento, estimated along the LOS of (a) ERS-1/2 in descending mode in 1992-2000 and (b) RADARSAT-1 in ascending mode in 2003-2007. The reference point location (green star) of the RADARSAT-1 dataset is also shown; ERS-1/2 reference point location is outside the figure.

to the displacements records of the series, but without altering their information content. This rescaling basically allowed the shift of all the motion estimates, from the processing master images (i.e., 1 August 1998 for ERS-1/2 and 23 September 2004 for RADARSAT-1) to the first date of each dataset. Thus, the motion records of the time series at a certain date correspond to the total motion occurred between that date and the first of the series.

\subsubsection{Addolorata landslide}

In the western sector of the town, where the Addolorata landslide occurred, many PS are identified in both the ERS-1/2 and the RADARSAT-1 datasets (Fig. 10). Most of these targets are located in the upper part of the landslide area, close to the crown and the zone of depletion, where many reflective structures, such as buildings and roads, can be detected. The majority of PS is identified only in the descending acquisition geometry, due to the local morphology of the area which is predominantly oriented in the SW, W and NW directions, and consequently prone to be analysed with PS descending data. Although the PS velocities in 1992-2000 are almost stable for a wide portion of the old translational slide, up to $-12 \mathrm{~mm} \mathrm{yr}^{-1}$ of LOS motions are observed close to the crown and main scarp of the landslide (e.g., $\mathrm{PS}_{\mathrm{a}}, \mathrm{PS}_{\mathrm{b}}$ and $\mathrm{PS}_{\mathrm{c}}$ in Fig. 10).

By using a simplified geomorphologic scheme, we assumed the motions affecting this area to be purely translational mechanisms. According to this assumption, we projected the LOS estimates to the most probable direction of displacement, i.e., the direction of the maximum slope. To this aim, we employed a DEM at $20 \mathrm{~m}$ resolution to estimate the directional cosines of the local slopes, and then implemented the approach described by Cigna et al. (2012). Accounting for the ground resolution of the input SAR imagery (i.e., $\sim 30 \mathrm{~m}$ ), the resolution of the employed DEM was considered suitable for this calculation.

PS velocities reprojected along the steepest slope direction showed up to $13-15 \mathrm{~mm} \mathrm{yr}^{-1}$ for the area of $\mathrm{PS}_{\mathrm{c}}$, and $18-20 \mathrm{~mm} \mathrm{yr}^{-1}$ for $\mathrm{PS}_{\mathrm{a}}$ and $\mathrm{PS}_{\mathrm{b}}$. These motions confirm that these sectors of the Addolorata landslide were still active 

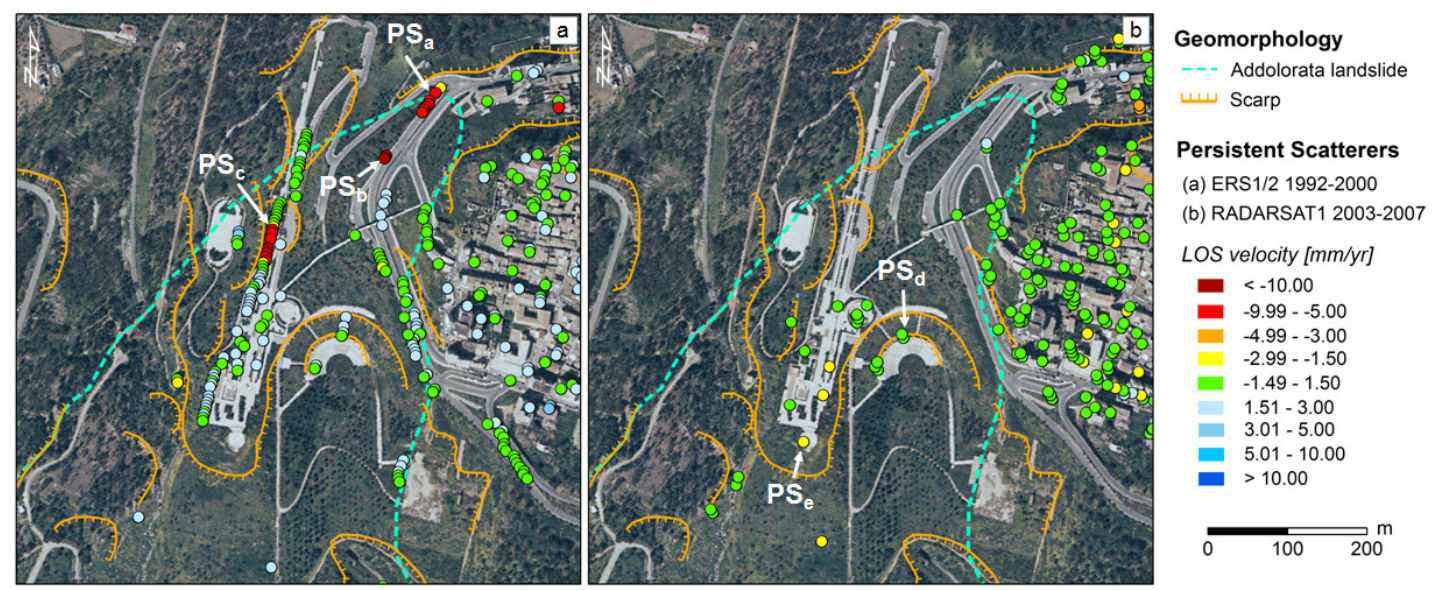

Fig. 10. PS motion velocities in the area of the Addolorata landslide, over the periods 1992-2000 (a) and $2003-2007$ (b). Time series of PS $\mathrm{PS}_{\mathrm{b}}, \mathrm{PS}_{\mathrm{c}}, \mathrm{PS}_{\mathrm{d}}$ and $\mathrm{PS}_{\mathrm{e}}$ are shown in Fig. 11.
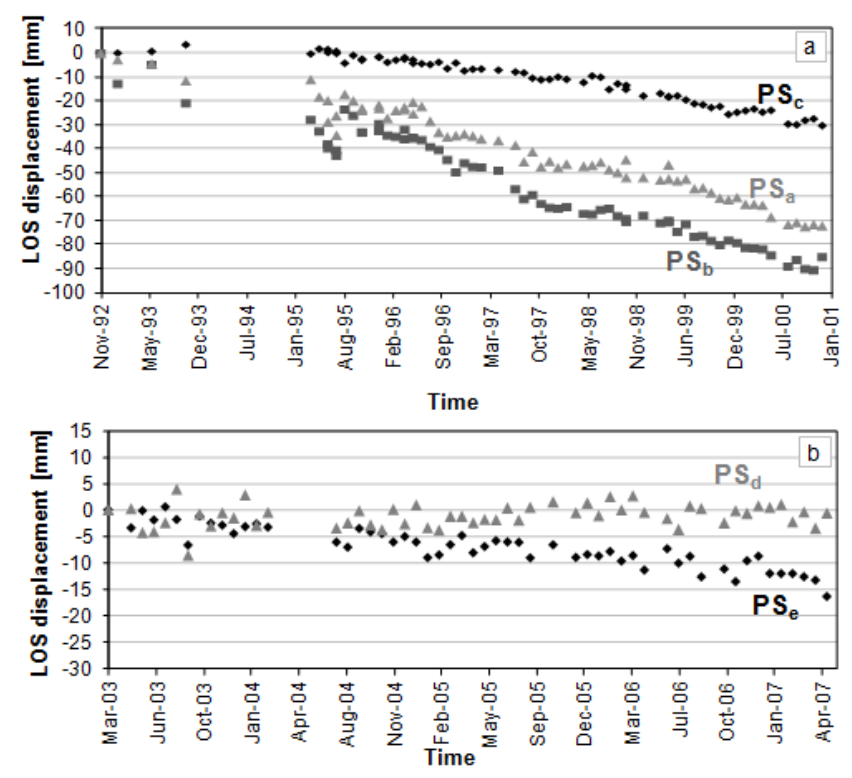

Fig. 11. Examples of 1992-2000 (a) and 2003-2007 (b) PS time series for the area of the Addolorata landslide (Fig. 10). Displacements are rescaled to the first acquisition of each dataset (i.e., 11 November 1992 for ERS-1/2 and 21 March 2003 for RADARSAT-1).

during the time interval 1992-2000, and had "extremely slow" $\left(\mathrm{PS}_{\mathrm{c}}\right)$ and "very slow" $\left(\mathrm{PS}_{\mathrm{a}}\right.$ and $\left.\mathrm{PS}_{\mathrm{b}}\right)$ velocities - according to the velocity scale of Cruden and Varnes (1996). The time series analysis of these PS shows an almost linear trend of deformation persisting between 1992 and 2000, with no major accelerations and/or decelerations (Fig. 11). ERS-1/2 PS coherence for the targets available over the Addolorata landslide range between 0.60 and 0.97 , hence the behaviour of the targets fit moderately to very well with the linear deformation model employed during the PSInSAR ${ }^{\mathrm{TM}}$ processing. However, the absence of nonlinearities within the time series can be a direct effect of the employment of the linear model. Thus, if any strong variations with respect to the linear model occurred during the monitoring period, they might had been discarded or smoothed during the processing itself.

Most of the RADARSAT- 1 targets show a general stability of the Addolorata area in 2003-2007, and their LOS motion velocities range between $\pm 1.5 \mathrm{~mm} \mathrm{yr}^{-1}$. This is likely due to the weak sensitivity of the ascending LOS to SW-oriented motions.

Only a few PS located in the central portion of the old Addolorata landslide highlight LOS motion velocities up to $-3 \mathrm{~mm} \mathrm{yr}^{-1}$ (e.g., $\mathrm{PS}_{\mathrm{e}}$ in Fig. 10). In this sector of the park, the slopes face SE and E, and slope-oriented motions are better seen by the ascending LOS. Conversion of LOS estimates to the steepest slope direction for this sector results in up to 6-7 $\mathrm{mm} \mathrm{yr}^{-1}$, hence "extremely slow" velocities.

RADARSAT-1 PS coherences range between 0.53 and 0.94, but apart from noise that can be observed over the entire monitoring period, no evident variations of the motion trend are recorded in 2003-2007 over this area.

The information gathered through the PSI data confirms the existence of ground instability in the Addolorata landslide crown area and, mainly, its northern surroundings; this agrees with location and magnitude of damages and cracks observed on the infrastructure of the Addolorata Park. As suggested by the Hydrogeological Setting Plan, localised sectors of the old landslide are currently affected by creep and land instability which affects the areas of the old translational slide. 


\subsubsection{Historic old town}

In the northwestern sector of the town, some ERS-1/2 and RADARSAT-1 PS are identified on the most damaged historic buildings such as St. Gerlando's Cathedral, the Diocesan Museum and the Bishop's Seminary, and many other urban structures (Fig. 12). In the steep slope located $\mathrm{N}$ of these buildings no radar target are identified, due to the lack of reflective structures and the presence of vegetation (causing high temporal decorrelation). Even with low densities of identified targets, here the information recorded by the satellite time series provides evidences supporting the interpretation of the damages observed over the historic buildings. The two PS datasets do not reveal significant values of yearly motion velocities in this area, as most of the targets are characterised by LOS rates ranging between $\pm 1.5 \mathrm{~mm} \mathrm{yr}^{-1}$. Exceptions are a few RADARSAT-1 points located at the edge of the hill, especially in correspondence with the north (left) aisle of St. Gerlando's Cathedral (Fig. 12).

In the northern portion of the churchyard just in front of the left aisle, and also close to the left part of the transept, LOS velocities of $-2.5 \mathrm{~mm} \mathrm{yr}^{-1}$ are observed (e.g., $\mathrm{PS}_{\mathrm{d}}$ ). By considering a purely vertical motion and the orientation of the RADARSAT- 1 LOS, the LOS values can be easily reprojected to the vertical direction. This is performed by dividing the LOS values by the cosine of the look angle $\theta$ of the RADARSAT-1 imagery (i.e., $32.3^{\circ}$ ).

Reprojected PS data suggest that velocities of $\sim 3.0 \mathrm{~mm} \mathrm{yr}^{-1}$ are recorded for this area in 2003-2007, which correspond to a total displacement of about $1.2 \mathrm{~cm}$ over the 4-yr long monitoring interval. As confirmed through the field surveys and recorded damages, these motions are compatible with the deformation observed on the façade and northern aisle of the Cathedral.

PS coherence over the historic quarter range between 0.60 and 0.81 for the ERS-1/2 dataset, and between 0.53 and 0.91 for the RADARSAT-1 dataset, hence the targets have a behaviour which fits moderately to very well with the linear deformation model of phase variation through time employed during the PSInSAR ${ }^{\mathrm{TM}}$ processing. Nevertheless, some deviations from the linear trends are detected for the historic buildings. For instance, the LOS motion velocity seems to accelerate to $-13 \mathrm{~mm} \mathrm{yr}^{-1}$ in the Cathedral churchyard starting in August 2006, and to persist until the end of the monitoring period, i.e., May 2007 (i.e., $\mathrm{PS}_{\mathrm{d}}$ in Figs. 12 and 13b). By assuming a purely vertical direction of motions, this velocity corresponds to $15 \mathrm{~mm} \mathrm{yr}^{-1}$, hence a total displacement of $1.1 \mathrm{~cm}$ over the last nine months of the monitoring period.

Additionally, a rapid movement of $-15 \mathrm{~mm}$ along the LOS is registered between August and September 1999 over the western side of the Bishop's Seminary, likely due to localised instability affecting the old building (Fig. 13a). By taking into account the orientation of the ERS-1/2 LOS, this motion corresponds to $1.6 \mathrm{~cm}$ if the assumption of purely vertical motion is made for this area. Since the magnitude of the observed step is lower than the phase ambiguity total step (which corresponds to $\lambda / 2$, i.e., $28 \mathrm{~mm}$ for C-band data), this motion is thought not to be due to a phase unwrapping error occurred during the PSInSAR ${ }^{\mathrm{TM}}$ processing.

The observed structural and deformational setting may be also influenced by the presence of hypogea (subterranean cavities) under the Seminary, the Bishop's Administration and the underlying slope, which were built during the 5th century BC with the aim of facilitating groundwater regimentation, drainage and supply (Ercoli, 1994). As observed during the field surveys in 2007 and 2011, the entrances of these cavities are currently affected by severe fracturing and progressive falls, and in the future may undergo further collapses with probable intensification and worsening of the instability conditions of the already unstable slope.

Even though the PS analysis in both 1992-2000 and 20032007 show quite low motion velocities over some of the most damaged areas of the northwestern slope, the presence of faster ground deformation should not be absolutely ruled out for these sectors. According to the outcomes from the geomorphologic and geostructural surveys, ground displacements occurring at the edge of the hill are likely characterised by significant motion components in the $\mathrm{N}-\mathrm{S}$ direction. Indeed, as discussed above, purely $\mathrm{N}-\mathrm{S}$ motion components are sensed by the employed LOS as $\sim 9 \%$ of their actual values. Moreover, it is worth considering that PS deformation data registered for the buildings of the historic town may not exactly represent the actual dislocation of the ground, since they are the outcomes of complex stress propagations (from the ground to the buildings), driven by the typology, construction materials, geometry and maintenance status of the buildings themselves and their foundations.

Some other PS located in the inner portion of the urban area show LOS velocities exceeding $\pm 1.5 \mathrm{~mm} \mathrm{yr}^{-1}$, but not clearly correlated with geological processes affecting the northwestern or the western sectors of Agrigento. These movements are likely to be related to local scale structural instability due to deterioration and/or instability processes affecting the old buildings of the historic urban area.

\section{Discussion and conclusions}

Most of the understanding on the instability conditions of the urban area of Agrigento comes from the extensive literature that already exists for the area of the Valley of the Temples, where a very similar geological and geomorphologic setting is observed (e.g., Cotecchia et al., 2005). Building upon this background knowledge, our combined study provided additional evidence on the instability currently affecting the historic town and the Addolorata quarter.

The tectonic deformation due to the development and evolution of the syncline, produced several systems of discontinuities, especially in the calcarenite of the Agrigento formation in the northwestern sector of the Girgenti hill and, 

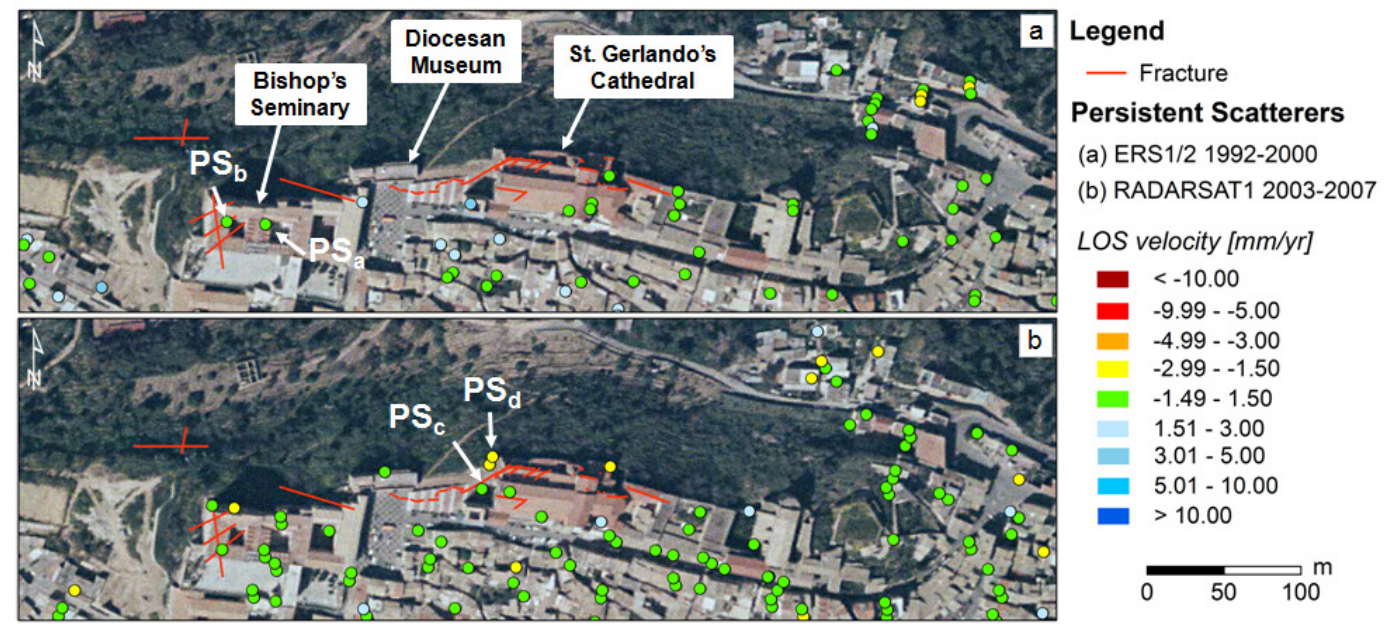

Fig. 12. PS motion velocities in the northwestern sector of Agrigento, over the periods 1992-2000 (a) and 2003-2007 (b). Time series of $\mathrm{PS}_{\mathrm{a}}, \mathrm{PS}_{\mathrm{b}}, \mathrm{PS}_{\mathrm{c}}$ and $\mathrm{PS}_{\mathrm{d}}$ are shown in Fig. 13.
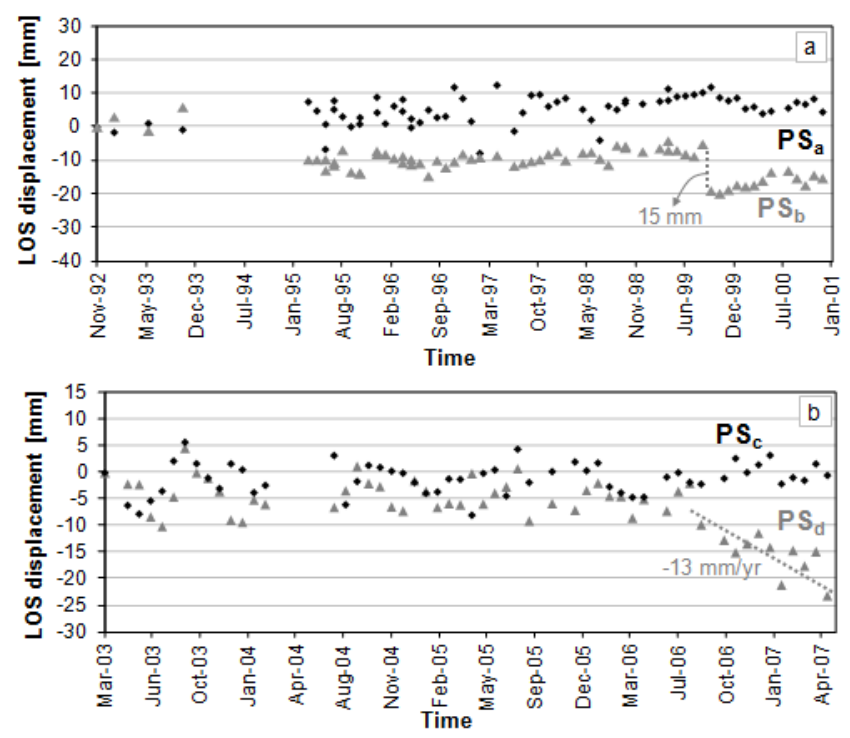

Fig. 13. Examples of 1992-2000 (a) and 2003-2007 (b) PS time series for the Seminary and the Cathedral of Agrigento (Fig. 12). Displacements are rescaled to the first acquisition of each dataset (i.e., 11 Nov 1992 for ERS-1/2 and 21 March 2003 for RADARSAT-1).

occasionally, in the sand deposits. On-site investigations and field surveys showed that the geomorphologic setting of the area is controlled by three main factors: (i) low quality of calcarenite rock masses over which the historic old town is built; (ii) remarkable contrast between different mechanical behaviours of the different facies of the Agrigento formation, which is coupled with locally unfavourable combination of stratigraphy and morphology; and (iii) widespread presence of erosion and slow landslides affecting the underlying clays of the Monte Narbone formation. These factors are clearly depicted in the geological and geomorphological maps of the area (Figs. 2 and 3), and their combination induces progressive retrogression of the biocalcarenite front on the northwestern sector of the Girgenti hill. It is also likely that since ancient times human activities reactivated and/or accelerated the gravitational processes affecting this area.

The interpretation of the results of the geomechanical survey and the kinematic analysis (Figs. 7 and 8 and Table 2) highlighted that the low quality of the rock mass underlying the Cathedral and the Seminary is due to the combination of a very poor quality of calcarenite - as intact rock with the structural weakening due to the distribution, spacing, aperture and persistence of discontinuities - even if the degree of fracturing of the rock mass can be classified as very low (i.e., high RQD). Although the properties of intact rock give usually a secondary contribution (with respect to that of the discontinuities) for the determination of the shear strength of rock masses, over this area they play a key role because the material constituting the intact rock has a very poor quality and a moderate degree of weathering and alteration. The outcomes of the kinematic analysis for the northwestern slope of the Girgenti hill showed also quite high indexes associated to toppling and wedge failure mechanisms for the slope underlying the historic old town, and confirm that the building and structural damages and ground motions observed are controlled by the presence of unfavourably oriented discontinuities.

The PSI analysis contributed to the understanding of the instability thanks to the opportunity to carry out a ground deformation study "in retrospect" by employing archive satellite data. The PS monitoring in 1992-2007 showed new and updated information about the ground motion scenario of the investigated areas, by contributing to the understanding of deformation velocities and behaviours. Significant 
displacements in the Addolorata landslide crown area were observed in 1992-2000, not only confirming over this area the presence of ground instability already identified by the Hydrogeological Setting Plan, but also allowing the quantification of their annual motion velocities (up to 18$20 \mathrm{~mm} \mathrm{yr}^{-1}$; "very slow" movements).

Additionally, in the northwestern sector of the urban area, where the historic old town is located, the PS analysis revealed the occurrence of a total motion of $1.2 \mathrm{~cm}$ in 2003 2007 in front of the north aisle of St. Gerlando's Cathedral, at the edge of the unstable slope. Sudden displacements of $1.6 \mathrm{~cm}$ were also estimated for the Bishop's Seminary in 1999. These movements are likely induced by the gradual retrogression of the underlying slope, due to fall, toppling and sliding of fractured calcarenite blocks of the Agrigento formation. Likelihood for the different instability mechanisms to occur is depicted by the kinematic analysis, which identifies the flexural toppling and wedge failure as the most probable movements characterising the northwestern slope. Progressive collapse of ancient hypogea may also play a role in the local instability, but this was not directly proven by the present analyses.

To overcome the lack of reflective structures in some sectors of the hill, the future installation of artificial radar targets (e.g., dihedral or trihedral corner reflectors) might be considered to activate future long-term monitoring of ground and structural instability with SAR sensors onboard new satellite constellations, such as the ESA Sentinel-1 to be launched in 2013.

The outcomes of this study and the long history of literature available for Agrigento suggest that the peculiar geomorphologic evolution and the deformational pattern of the area of Agrigento should be taken into consideration for planning any future mitigation measure aimed to reduce the impacts on the elements at risk, both the inhabitants and the cultural heritage. The ground instability in the northwestern sector of the Girgenti hill causes severe structural problems in the historic buildings of the Cathedral and the Seminary, whose stability and safe accessibility are nowadays almost compromised.

Acknowledgements. This work was performed in the framework of the Italian projects "SAR.net", funded by the Italian Civil Protection Department, and "Interpretazione di dati telerilevati per lo studio delle condizioni di dissesto nel Comune di Agrigento e nel centro abitato di Naro", funded by the Regional Civil Protection Department (DRPC), Sicily. P. Farina, D. Mattina and G. Manno are acknowledged for their contribution to this research. Further thanks go to TRE S.r.l. for processing the ERS-1/2 and RADARSAT-1 imagery with PSInSAR ${ }^{\mathrm{TM}}$ and for their cooperation.

Edited by: R. Lasaponara

Reviewed by: T. Farr and one anonymous referee

\section{References}

Barton, N. R. and Choubey, V.: The shear strength of rock joints in theory and practice, Rock Mechanics, 10, 1-54, 1977.

Bianchini, S., Cigna, F., Righini, G., Proietti, C., and Casagli, N.: Landslide HotSpot Mapping by means of Persistent Scatterer Interferometry, Environ. Earth Sci., 67, 1155-1172, doi:10.1007/s12665-012-1559-5, 2012.

Casagli, N. and Pini, G.: Analisi cinematica della stabilità in versanti naturali e fronti di scavo in roccia, Geologia Applicata e Idrogeologia, 28, 223-232, 1993.

Cigna, F., Del Ventisette, C., Liguori, V., and Casagli, N.: Advanced radar-interpretation of InSAR time series for mapping and characterization of geological processes, Nat. Hazards Earth Syst. Sci., 11, 865-881, doi:10.5194/nhess-11-865-2011, 2011.

Cigna, F., Bianchini, S., and Casagli, N.: How to assess landslide activity and intensity with Persistent Scatterer Interferometry (PSI): the PSI-based matrix approach, Landslides, 1-17, doi:10.1007/s10346-012-0335-7, 2012.

Colesanti., C., Ferretti, A., Prati, C., and Rocca, F.: Monitoring landslides and tectonic motions with the Permanent Scatterers Technique, Eng. Geol., 68, 3-14, 2003.

Commissione Ministeriale LL. PP.: La frana di Agrigento, Relazione tecnica, In: Lerici (Ed.), Città Spazio, 1-2, 13-62, 1968.

Cotecchia, V., Fiorillo, F., Monterisi, L., and Pagliarulo, R.: Slope Instability in the Valley of Temples, Agrigento (Sicily), Giornale di Geologia Applicata. 1, 91-101, 2005.

Cruden, D. M. and Varnes, D. J.: Landslide types and processes, in: Landslides: Investigation and Mitigation, edited by: Turner, A. K. and Schuster, R. L., Sp. Rep. 247, Transportation Research Board, National research Council, National Academy Press, Washington DC, 36-75, 1996.

Deere, D. U.: Technical description of rock cores, Rock Mech. Eng. Geol., 1, 16-22, 1964.

Ercoli, L.: Gli ipogei dell'antica Akragas in rapporto all'assetto geostrutturale della formazione di Agrigento, in: Atti VIII Congresso Scienze della Terra e Trasformazioni Antropiche, 2123 January 1994, Rome, Italy, 509-518, 1994.

Farina, P., Colombo, D., Fumagalli, A., Marks, F., and Moretti, S.: Permanent Scatterers for landslide investigations: outcomes from the ESA-SLAM project, Eng. Geol., 88, 200-217, 2006.

Ferretti, A., Prati, C., and Rocca, F.: Permanent Scatterers in SAR interferometry, IEEE T. Geosci. Remote, 39, 8-20, 2001.

Fisher, R.: Dispersion on a sphere, Proc. Royal Society London, A217, 295-305, 1953.

Gigli, G., Frodella, W., Mugnai, F., Tapete, D., Cigna, F., Fanti, R., Intrieri, E., and Lombardi, L.: Instability mechanisms affecting cultural heritage sites in the Maltese Archipelago, Nat. Hazards Earth Syst. Sci., 12, 1883-1903, doi:10.5194/nhess-121883-2012, 2012.

Goodman, R. E. and Bray, J. W.: Toppling of rock slopes, Proc. Special Conference on Rock Engineering for Foundations and Slopes, ASCE, Boulder (Colorado), 2, 201-234, 1976.

Grasso, M., and Butler, R. W. H.: Tectonic controls on the deposition of late Tortonian sediments in the Caltanissetta basin of central Sicily, In: Atti del convegno Giornate in memoria di Leo Ogniben, Mem. Soc. Geol. It., XLVII, 313-324, 1991. 
Herrera, G., Davalillo, J. C., Mulas, J., Cooksley, G., Monserrat, O., and Pancioli, V.: Mapping and monitoring geomorphological processes in mountainous areas using PSI data: Central Pyrenees case study, Nat. Hazards Earth Syst. Sci., 9, 1587-1598, doi:10.5194/nhess-9-1587-2009, 2009.

Hilley, G. E., Bürgmann, R., Ferretti, A., Novali, F., and Rocca, F.: Dynamics of slow-moving landslides from Permanent Scatterer analysis, Science, 304, 1952-1955, 2004.

Hoek, E. and Bray, J. W.: Rock Slope Engineering, Revised 3rd Edn., Institution of Mining and Metallurgy, London, 1981.

Hölbling, D., Füreder, P., Antolini, F., Cigna, F., Casagli, N., and Lang, S.: A Semi-Automated Object-Based Approach for Landslide Detection Validated by Persistent Scatterer Interferometry Measures and Landslide Inventories, Remote Sens., 4, 13101336, 2012.

Hudson, J. A. and Harrison, J. P.: Engineering rock mechanics, Pergamon Ed., 1997.

Hudson, J. A. and Priest, S. D.: Discontinuity frequency in rock masses, Int. J. Rock Mech. Min. Sci. Geomech. Abstr., 20, 7389, 1983.

ISPRA: Rapporto sulle frane in Italia, Rapporti ISPRA, 78/2007, available at: http://www.isprambiente.gov.it/it/pubblicazioni/ rapporti/Rapporto-sulle-frane-in-Italia (last access: November 2012), 2007.

ISRM: Suggested methods for the quantitative description of discontinuities in rock masses, Int. J. Rock Mech. Min. Sci. Geomech. Abstr., 15, 319-368, 1978.

ISRM: Suggested methods for determining Point Load strength. Int. Jour. Rock Mech. Min. Sci. and Geomech. Absr., 22, 51-60, 1985.

Lickorish, W. H., Grasso, M., Butler, R. W. H., Argnani, A., and Maniscalco, R.: Structural style and regional tectonic setting of the Gela Nappe and frontal part of the Maghrebian thrust belt in Sicily, Tectonics, 18, 655-668, 1999.
Meisina, C., Zucca, F., Fossati, D., Ceriani, M., and Allievi, J.: Ground deformations monitoring by using the Permanent Scatterers Technique: the example of the Oltrepo Pavese (Lombardia, Italy), Eng. Geol., 88, 240-259, 2006.

Musso, A. and Ercoli, L.: Monuments and landslides in the Agrigento valley, in: The engineering geology of ancient works, monuments and historical sites, edited by: Marinos, P. G. and Koukis, G. C., A.A. Balkema, Rotterdam, 113-121, 1988.

PCM: Ordnance no. 3450, 16/07/2005, Primi interventi urgenti di protezione civile diretti a fronteggiare la situazione emergenziale, inerente ai gravi dissesti idrogeologici con conseguenti movimenti franosi in atto nei territori dei comuni di Agrigento e di Naro, G.U. no. 169, 22 July 2005, 2005.

Regione Siciliana: Piano Stralcio di Bacino per l'Assetto Idrogeologico (PAI), Bacino Idrografico del Fiume San Leone ed Area Intermedia compresa fra i Bacini del F. San Leone e del F. Naro (067), available at: http://www.sitr.regione.sicilia.it/ (last access: 16 August 2012), 2006.

Righini, G., Pancioli, V., and Casagli, N.: Updating landslide inventory maps using Persistent Scatterer Interferometry (PSI), Int. J. Remote Sens., 33, 2068-2096, 2012.

Servizio Geologico D'Italia: Foglio Geologico 636, Agrigento. Carta geologica d'Italia 1:50.000, Ente Minerario Siciliano, 1972.

Tapete, D. and Cigna, F.: Rapid mapping and deformation analysis over cultural heritage and rural sites based on Persistent Scatterer Interferometry, Int. J. Geophys., 618609, doi:10.1155/2012/618609, 2012.

Tapete, D., Fanti, R., Cecchi, R., Petrangeli, P., and Casagli, N.: Satellite radar interferometry for monitoring and early-stage warning of structural instability in archaeological sites, J. Geophys. Eng., 9, S10-S25, doi:10.1088/1742-2132/9/4/S10, 2012.

WP/WLI: Multilingual Glossary for Landslides, The Canadian Geotechnical Society, BiTech Publisher, Richmond BC, 1993. 